\title{
GENERAL INSPECTOR OF FINANCIAL INFORMATION AS AN ANTI-MONEY LAUNDERING BODY
}

\section{DARIUSZ PAUCH}

University of Szczecin, Faculty of Management and Economics of Services, POLAND

e-mail: dariusz.pauch@usz.edu.pl

\begin{tabular}{|c|c|}
\hline $\begin{array}{l}\text { RECEIVED } \\
\text { ACCEPTED }\end{array}$ & $\begin{array}{l}18 \text { January } 2018 \\
2 \text { September } 2018\end{array}$ \\
\hline $\begin{array}{l}\text { JEL } \\
\text { CLASSIFICATION }\end{array}$ & $\mathrm{G} 2, \mathrm{H} 2$ \\
\hline KEYWORDS & General Inspector of Financial Information, money laundering, grey market \\
\hline ABSTRACT & $\begin{array}{l}\text { The article attempts to indicate the role and importance of the General Inspector of Financial Information (GIFI) } \\
\text { as one of the main authorities limiting money laundering in Poland. Considerations began with the definition } \\
\text { of money laundering under Polish and international law. Next, the phases and methods of money laundering } \\
\text { were specified and the ways of limiting the above-mentioned practices were presented. The next part discusses } \\
\text { in detail the functions and tasks of the GIFI. Attention was paid to the scope of activities and units cooperating } \\
\text { with the GIFI within the framework of the fight against money laundering in Poland were indicated. A summary } \\
\text { of the consideration has been presented in the final conclusions. }\end{array}$ \\
\hline
\end{tabular}

\section{Introduction}

Organized crime is a criminal phenomenon that occurs on an international scale and it includes not only the collection of individual crimes, it is also characterized by a complex form of antisocial behaviors. It is a phenomenon known for a long time, occurs in many countries, in various forms, and the subject of its interest is various areas of socio-economic life. Along with the socio-economic progress, criminal phenomena have intensified. They have 
a source in the activities of organized crime groups that legalize their income from criminal activities, such as financial and tax frauds, drug trafficking, arms trafficking or prostitution.

The phenomenon of money laundering is very difficult to control, especially in certain types of business activity. Skillful overstating of revenues enables to enter illegally earned cash into the general trading system. This can be achieved by, inter alia, establishing a business with cash trading, strictly in service. In Poland, the General Inspector of Financial Information (GIFI) is the central element of the national system of counteracting money laundering and terrorism financing. The legal basis for his activity is the Anti-Money Laundering and Terrorism Financing Act of 16 November 2000 (Ustawa o przeciwdziałaniu..., 2000). The GIFI supervises the Polish Financial Intelligence Unit (PFIU), to which all information about suspicious transactions flows. Thanks to this, a system of fighting against criminal activity, which launders money, is formed. Due to the international dimension of money laundering and terrorism financing, the PFIU exchanges information with foreign financial intelligence units.

The aim of this article is to present the practice of money laundering with particular emphasis on the activities of the GIFI in the aspect of counteracting the above-mentioned practice.

\section{The money-laundering phenomenon}

The money-laundering phenomenon was first noticed in the 1920s in the United States. The mafia led by Al Capone profited from the illegal activity connected with, among others, smuggling and sale of alcohol. In order to hide the fraudulent activity, members of the criminal group were carried out legal business activities, i.e. laundries. The incomes obtained from this criminal activity could be freely added to takings in order to hide their true origin.

In the Polish law, definitions of "money laundering" can be found in the Act of 16 November 2000 on counteracting money laundering and financing of terrorism. Article 2 point 9 of this Act determines money laundering as intentional proceedings connected with:

a) exchange or transfer of property values derived from a criminal activity or from participating in such activity, in order to hide or conceal the unlawful origin of these property values or the provision of assistance to a person, who participates in such activities in order to avoid legal consequences of such activities;

b) hiding or concealing the true nature of property values or rights associated with them, their source, place of storage, disposal and the fact of their movement, knowing that these values are derived from criminal activities or participation in such activities;

c) acquiring, taking possession or using property values derived from criminal activities or participation in such activities;

d) cooperating, attempting to commit, aiding or abetting in the cases of behaviors determined in letters a-c; also if the activities, under which the property values were obtained, were carried out on the territory of a country than the Republic of Poland.

The definition of money laundering is contained in Article $299 \S 1$ of the Polish Penal Code of 6 June 1997 (Ustawa z dnia 6 czerwca..., 1997). This article determines this phenomenon in the following way: Anyone who receives, transfers or transports abroad, or assists in the transfer of title or possession of legal tender, securities or other foreign currency values, property rights or real or movable property obtained from the profits of offences committed by other people, or takes any other action that may prevent or significantly hinder the determination of their criminal origin or place of location, their detection or forfeiture, is liable to imprisonment for between six months and eight years. 
On the basis of the Penal Code, solutions, related to combating money laundering phenomenon for, among other, breaking down organized crime groups involved in this type of practices, were introduced. According to Article $299 \S 8$ of the Penal Code, anyone who, by voluntarily reporting information to a prosecutor about people committing an offence or about the circumstances of an offence, prevented another offence from being carried out, is not liable to the penalty for the offence of money laundering. ${ }^{1}$

Within the framework of the Directive 2005/60/EC of the European Parliament and the Council of 26 October 2005 on the prevention of the use of the financial system for the purpose of money laundering and terrorist financing, the money laundering is defined as the following acts committed intentionally:

a) conversion of transfer of property, with the knowledge that it comes from criminal activity or from participation in such activities, to conceal of hide the illegal origin of this property or to assist the person, who participates in such activity, in order to enable such a person to avoid the legal consequences of such activity;

b) hiding or concealing the true character of the property, its source, location, disposal, movement, property or rights to property, knowing that such a property is derived from criminal activity of from participating in such activity;

c) acquisition, possession or use of property, knowing, at the time of receipt, that the property comes from a criminal activity or from participating in such activity;

d) participation or cooperation in committing, attempting to commit, as well as aiding, abetting, facilitating and advising in committing acts specified in the above-mentioned points

However, according to the definition of the US Treasury Department Training Center, money laundering is "a process by which the incomes supposedly obtained from criminal activity are transferred, transformed, exchanged or combined and mixed with legal funds in order to conceal or hide the true nature, source, orientation, flow or ownership or such incomes. The purpose of the money laundering process is to give the appearance of legality for funds obtained from non-legal activities or activities related to them".

In other words, this is a practice of "legalizing" illegally obtained money, for example, from prostitution, drug trafficking, arms trafficking, etc. The name itself originated from the fact the most common form of money laundering were service points, where it was difficult to control real incomes, so it was easy to overstate them. Laundries were often used to this practice, hence the name of this practice. This name well reflects its character and refers to its history (Sadło, 2011, p. 7).

The authors dealing with the money-laundering phenomenon assume that the above phenomenon may take place in three consecutive stages:

1. Placement (introduction to financial training).

2. Masking (separation of funds from an illegal source).

3. Integration (creating an explanation for the origin of resources), i.e. from the moment of introducing illegal funds to financial trading to their legalization (Ministerstwo Finansów, 2004, pp. 47-48)

4. Each of the above-mentioned forms realizes the following functions (Pływaczewski, 1993, p. 18):

${ }^{1}$ Persons involved in crime are accomplices, leadership perpetrators, perpetrators (recommendators), instigators and helpers, even if they did not bear criminal responsibility. 
a) overcoming barriers related to the submission of foreign exchange declarations (statements) for the export and import of cash;

b) entry into the national (international) financial system;

c) camouflage by joining the legal financial system;

d) bringing purified money (linking them) to the destination country.

\section{Activity of the Genepal Inspector of Financial Information}

The system of combating money laundering and financing of terrorism in created in Poland by:

- General Inspector of Financial Information,

- obligated institutions,

- cooperating units.

Within the framework of obligated institutions, there are: banks, cooperative savings and credit unions, brokerage houses, insurance companies, tax advisors, statutory auditors, accountants, notaries, legal advisers and lawyers, companies conducing leasing or factoring activity, entities operating in the field of currency exchange, investment funds and public operators within the meaning of the Postal law. Within the cooperating units, there can be distinguished organs of government administration and local government, as well as other state organizational units and the National Bank of Poland and the Polish Financial Supervision Authority and the Supreme Chamber of Control.

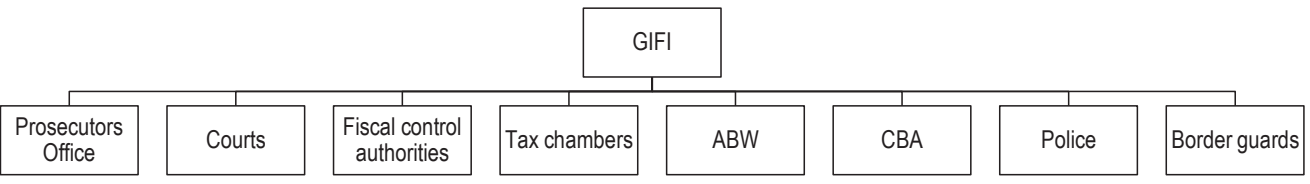

Figure 1. Types of cooperating units of the GIFI

Source: own study based on the Act of 16 November 2000 on counteracting money laundering and financing of terrorism.

In the realization of its statutory tasks, the GIFI is assisted by the Financial Information Department of the Ministry of Finance, which acts as the Polish Financial Intelligence Unit (PFIU).

The organs of government administration competent in matters of counteracting money laundering and financing of terrorism are (the Act on counteracting money laundering and financing of terrorism):

1. The minister competent for financial institutions as the main body of financial information.

2. The General Inspector of Financial Information. The General Inspector is appointed and dismissed by the Prime Minister at the request of the minister competent for financial institutions.

Pursuant to Article 4 of the Act on counteracting money laundering and financing of terrorism, the General Inspector's tasks include obtaining, collecting, processing and analyzing information in the mode specified in the Act and undertaking actions to counteract money laundering and financing of terrorism, in particular:

a) examination of the course of transaction, for which the General Inspector had reasonable suspicions;

b) realization of the transaction suspension or account blocking procedure;

c) settlement in the subject of releasing freezing property values; 
d) providing and requesting information about transactions;

e) provision of documents justifying the suspicion of committing a crime to the authorized bodies;

f) initiating and undertaking other actions to counteract money laundering and financing of terrorism, including training of employees in obligated institutions in the scope of tasks imposed on these institutions;

g) control over compliance with the provisions on counteracting money laundering and financing of terrorism;

h) cooperation with foreign institutions and international organizations involved in counteracting money laundering or financing of terrorism;

i) imposing fines, referred to in the Act.

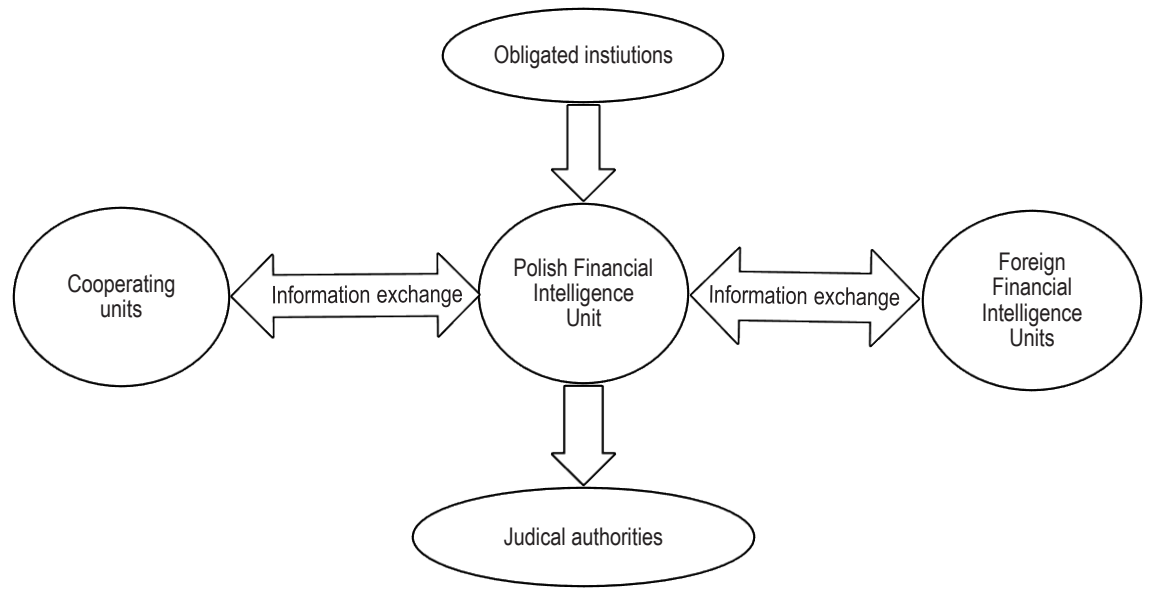

Figure 2. Diagram of obtaining and exchanging information within the activity of the Polish Financial Intelligence Unit Source: own study based on the Act of 16 November 2000 on counteracting money laundering and financing of terrorism.

With the framework of transaction monitoring, the GIFI collects information on two categories of transactions: concerning above-threshold transactions and concerning suspicious transactions.

Above-threshold transactions are transactions that exceed 15 thousand euros (one thousand euros for some types of obligated institutions. This means that the Ministry of Finance collects information on each transfer, purchase of item, payment, withdrawal or other operation made for an amount greater than 15 thousand euros (the Act on counteracting money laundering and financing of terrorism).

In the case of suspicious transactions, information related to the offense is distinguished:

1. SARs (Suspicious Activity Reports), descriptive reports on activities and suspicious transactions, which contain a description of a few, several or several hundred transactions (often related to each other by the parties of transactions, circumstances of performance, similar time of completion or involvement of the same property values).

2. STRs (Suspicious Transaction Reports), which can take a twofold form: STR-ML (Suspicious Transaction Reports on Money Laundering) it may be related to money laundering; STR-TF (Suspicious Transaction Reports on Terrorist Financing) information that may be related to the financing of terrorism. 


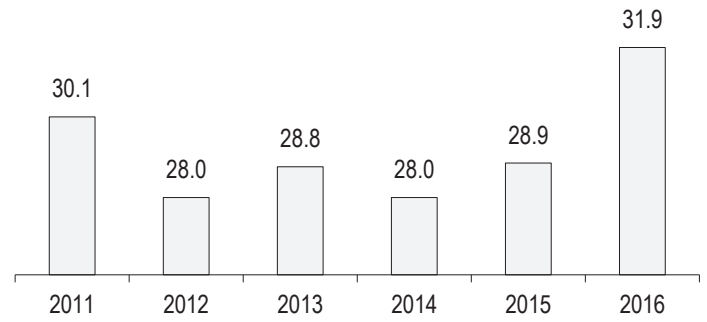

Figure 3. Number of information about above-threshold transactions received by the GIFl in the years 2011-2016 (in millions)

Source: own study based on Ministerstwo Finansów (2017), p. 10.

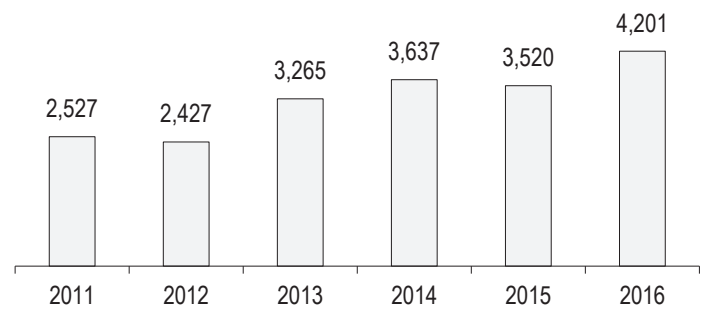

Figure 4. Number of SARs reported to the GIFI in the years 2011-2016

Source: own study based on Ministerstwo Finansów (2017), p. 9.

SARs - in comparison to notifications on individual suspicious transactions - contain more information, especially regarding the suspected offenses committed by the obligated institutions and the circumstances accompanying the transactions. Such a wide information spectrum enables faster verification of data received in other sources of information and shortens the time for the realization of activities undertaken by the GIFI in cooperation with the prosecutor's office and law enforcement authorities.

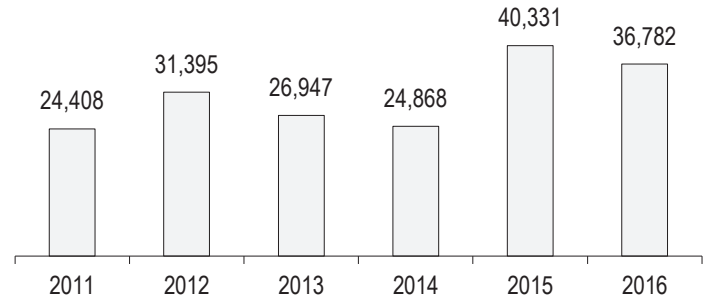

Figure 5. Number of STRs reported to the GIFI in the years 2011-2016

Source: own study based on Ministerstwo Finansów (2017), p. 9. 
The values presented by the GIFI indicate a large disproportion between the amount and significant of information obtained by state authorities on the private affairs of citizens and the low rate of benefits obtained in this way by the state. Large reservations may be roused by automatic collection of information about each abovethreshold transaction. It would be possible to focus in a greater extent on suspicious transactions. In this way, the GIFI obtains a very large amount of data, which probably is not able to analyze effectively. Additionally, there is a huge database of confidential citizens' affairs, which may be used by unauthorized persons to interfere with privacy.

The above consideration are confirmed by the results of the Supreme Chamber of Control (Polish: NIK; Najwyższa Izba Kontroli, 2016) regarding the system of counteracting money laundering and financing of terrorism. The NIK indicates that in 2014 the GIFI carried out 2.4 thousand proceedings, while only 170 notifications about suspicion of committing money laundering were directed to the prosecutor's office. Moreover, the NIK notes that in the audited period (from beginning of 2013 to mid-2015), the effectiveness of the system of supervision over institutions obliged to register above-threshold transactions and suspicious people was at a low level. This can be confirmed by the fact that at the level of money laundering estimated at 18.2 billion PLN (in 2014), in criminal proceedings, the property was secured for only 1.2 billion PLN and the forfeiture of assets in the amount of 11.5 million PLN was declared. This presents only $0.07 \%$ of the estimated amount. On the other hand, in 2015 , the scale of money laundering phenomenon was estimated at 17 billion PLN. This time, property to the amount of 3 million PLN was secured in criminal proceedings and property forfeiture of about 100 million PLN was declared. This is $0.6 \%$ of the estimated amount.

Another aspect indicated by the Supreme Chamber of Control is the fact that the Minister of Finance did not regulate the issue of supervision over the functioning of on-line exchange offices. It should be noted that such exchange offices are not subject to any scope of anti-money laundering controls. However, none of the legal acts refers to on-line exchange offices, because they appeared only in 2009. It should be emphasized that on-line currency exchange market is growing year by year. As estimated by Currency One S.A., in 2015, currency exchange was conducted in Poland through to approx. 25 billion PLN. On the other hand, in 2016, the turnover on the market is to exceed 30 billion PLN (Raport..., 2015, p. 22).

\section{Conclusions}

Counteracting money laundering and financing of terrorism is one of the important tasks of the state aimed at limiting crime and ensuring security. Detection and prosecution of crime connected with money laundering and financing of terrorism is a difficult task, requiring the cooperation of many state bodies and services, as well as international cooperation. The practice of concealing the actual origin of cash from criminal activities is primarily related to the functioning of organized crime. It is estimated that the value of laundered money can reach up to $5 \%$ of global GDP annually. The development of the underground economy may reach $2-11 \%$ of Germany's GDP, $10-13 \%$ of Japan's GDP and 4-33\% of USA's GDP (Smolak, 2013).

Both the appointment of a professional financial intelligence unit - the General Inspector of Financial Information, as well as amendments to Article 299 of the Penal Code (that enabled the implementation of European standards to the Polish system of combating the above-mentioned practice) were extremely important in this respect. The amendment to the Polish Act on counteracting money laundering and financing of terrorism of 2009, in which new financial instruments to combat money laundering include financial penalties imposed on institutions 
failing to meet their obligations, should be assessed positively. This is a positive signal for the increase in the involvement of state authorities in the fight against the legalization of "dirty" income.

It is appropriate that many financial institutions and other entities that make it possible to detect a crime were included to the counteraction system. Obligated institutions and cooperating units, as a part of the procedures, are obliged to inform the GIFI about cases of excessively spent money. All these stages fall under the procedural actions of these units and they are realized with the participation of the General Inspector and cooperating units.

\section{References}

Dyrektywa 2005/60/WE Parlamentu Europejskiego i Rady z dnia 26 października 2005 r. w sprawie przeciwdziałania korzystaniu z systemu finansowego w celu prania pieniędzy oraz finansowania terroryzmu.

Ministerstwo Finansów, Generalny Inspektor Informacji Finansowej (2004). Przeciwdziałanie praniu pieniędzy i finansowaniu terroryzmu. Poradnik dla instytucji obowiązanych i jednostek współpracujących. Warszawa.

Ministerstwo Finansów (2017). Sprawozdanie Generalnego Inspektora Informacji Finansowej z realizacji ustawy z dnia 16 listopada 2000 r. o przeciwdziałaniu praniu pieniędzy i finansowania terroryzmu w 2016 roku. Warszawa.

Najwyższa Izba Kontroli (2016). System przeciwdziałania praniu pieniędzy oraz finansowaniu terroryzmu. Warszawa.

Pływaczewski, E. (1993). Proceder prania brudnych pieniędzy. Studia i materiały. Toruń: Wydawnictwo Dom Organizatora.

Raport „Kantory Online 2015” (2015). Interaktywnie.com. Retrieved from: https://interaktywnie.com/biznes/newsy/raporty-i-badania/ raport-kantory-online-2015-251508.

Sadło, K. (2001). Ustawa o przeciwdziałaniu praniu pieniędzy i finansowaniu terroryzmu - obowiązki organizacji pozarządowych. Warszawa: Fundacja Rozwoju Społeczeństwa Obywatelskiego.

Smolak, M. (2013). Formy zwalczania procederu prania brudnych pieniędzy. Przegląd Bezpieczeństwa Wewnętrznego, 9 (13), $294-305$. Ustawa o przeciwdziałaniu praniu pieniędzy oraz finansowaniu terroryzmu z 16 listopada 2000 r. Dz.U. of 2000, no. 116, item. 1216. Ustawa z dnia 6 czerwca 1997 r. - Kodeks Karny. Dz.U. 1997, no. 88, item. 553.

Cite this anticle aS: Pauch, D. (2018). General Inspector of Financial Information as an anti-money laundering body. European Journal of Service Management, 3 (27/2), 323-330. DOI: 10.18276/ejsm.2018.27/2-39. 